\title{
Clinical presentation and surgical management of Glomatosis Cerebri
}

\author{
${ }^{1}$ Mohamed Youssef ALQazaz, M.D., Ph.D. ${ }^{2}$ Mohamed Elsamahy MD \\ ${ }^{1}$ Assistant professor of Neurosurgery, ${ }^{2}$ Lecturer of Neurology, Faculty of Medicine, Suez \\ Canal University, Ismailia, Egypt. \\ Correspondence author:
}

Dr. Mohamed Elsamahy MD

Department of Neurology, Faculty of medicine, Suez Canal University, 4.5 Kilo of the round road, Ismailia, Egypt.

Email: mohelsamahy7@yahoo.com

\begin{abstract}
Background: Glomatosis Cerebri (GC) is a diffuse brain neoplasm whose prognosis is unfavourable. Aim: to investigate the clinical presentation, radiological and pathological features, and outcomes after treatment of GC. Patients and Methods: We collected data from fifteen patients with GC treated at Suez Canal University, during a ten-year period. The diagnosis was based on magnetic resonance imaging (MRI) findings and tissue biopsy of all patients except one patient who received blind radiotherapy. Results: Seven patients were male (47\%), and their median age at presentation was 43 years (range, 6-75 years). Statistical analysis demonstrated median survival as follows: blind radiotherapy, 1 month $(\mathrm{n}=1)$; biopsy then radiotherapy, 19 months (8-32 months; $\mathrm{n}=9$ ); subtotal excision then radiotherapy, 5 months (1-7 months; $n=5)$. Karnofsky Performance Scale scores of $\geq 70$ and tumor grade were both significantly related to length of survival. Conclusion: Our findings suggest that biopsies are useful not only for diagnosis but also for prediction of the length of survival.
\end{abstract}

Key Words: GC, Outcome, Biopsy, Radiotherapy. 
الملخص: تعتبر الجليوما المخيه هو ورم دماغي منتشر غامض يكون تكهناته قاتمة. الهُف من الدراسة: كان

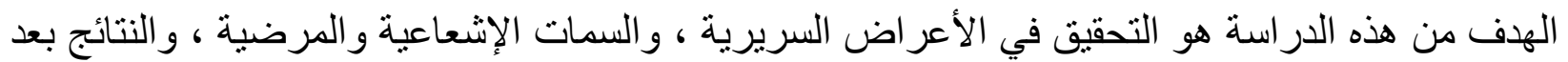

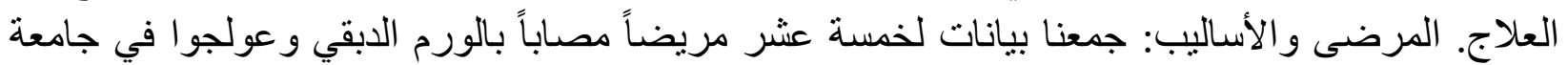

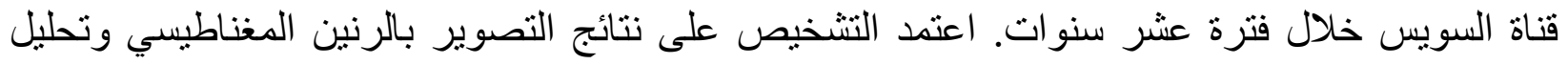

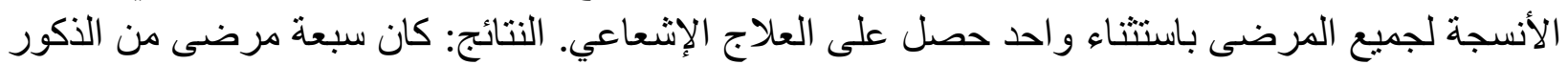
(47 \%) ، وكان منوسط العمر عند التشخيص 43 سنة (المدى من 6 - 75 سنة) .

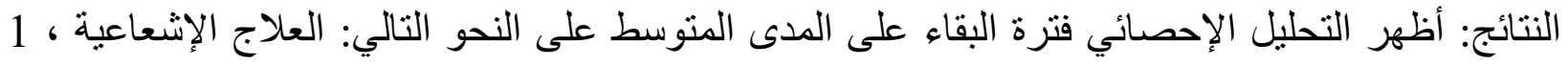

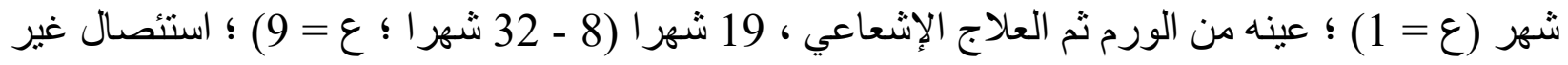

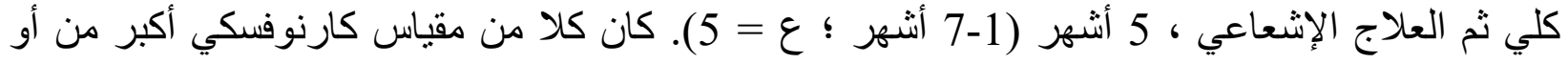

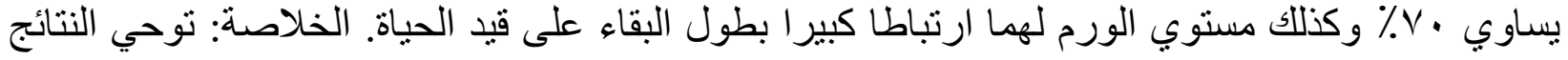

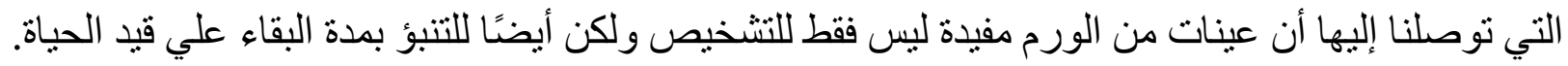




\section{INTRODUCTION:}

GC [GC] is a rare primary neuroepithelial brain tumor first described clinically in 1897 . Nevin subsequently coined the term GC in 1938 [1, 2]. It is defined by WHO as a diffuse tumor infiltrating the brain with neoplastic glial cells [astrocytoma and/or oligodendroglioma] extensively, involving more than two lobes, frequently bilaterally and often extending to infratentorial structures and even the spinal cord. It frequently involves extension into the corpus callosum, the basal ganglia, the thalamus, the brainstem, and/or the cerebellum [3]. It may be difficult to distinguish GC from highly infiltrate anaplastic astrocytoma or GBM except by biopsy that confirm the diagnosis of GC [4].

Gliomatosis can occur at any age but is usually found in the third and fourth decades of life [5]. Patients most frequently present with personality and mental changes [6]. On MRI, it appears as a diffuse, poorly circumscribed, infiltrating lesion that is hyperintense on T2-weighted images and expands the cerebral white matter with marked parenchymal involvement. Enhancement is uncommon. The prognosis for GC is generally poor, with a median survival time of only 12 months [7].

There are different modalities of management of GC. The first procedure, if the tumor is accessible, is surgery. If surgery is not an option, a biopsy might be recommended to confirm the type of tumor [8]. Radiation therapy usually follows the surgical procedure [9].

Here we present a series of $15 \mathrm{GC}$ cases in which 14 patients underwent biopsies for histopathological confirmation of the disease. The purpose of our study was to better define the presentation, outcome, and the reasonable way of management of GC.

\section{PATIENTS AND METHODS}

During February 2006 to September 2016, we retrospectively followed fifteen patients [seven males and eight females] with GC in department of neurosurgery at Suez Canal University hospital. Information on the patients' clinical history and signs, surgical approach, pathology and outcomes were recorded.

In this study, patients were included if they met the following criteria:

1) Availability of clinical data, including complete history and neurological examination results, and relevant laboratory data (Table 1).

2) MRI evidence of a diffuse infiltrative process involving more than two cerebral lobes (frequently bilaterally) and often extending to infra tentorial structures. 
We excluded patients who initially presented with a focal glioma (low or high grade) limited to one brain lobe and then developed widespread contiguous tumor infiltration into adjacent brain tissue on follow-up imaging scans.All patients in this study underwent clinical follow-up, including treatment documentation and serial MRI studies (Table 1). Therefore, all patients were either alive at the time of this study $(n=5)$ or had died $(n=10)$.

Fourteen patients underwent brain tissue removal for pathological examinations; nine patients underwent biopsy, either stereotactic (five patients) or open (four patients), and five patients underwent craniotomy and resection of a dominant mass. All patients were reexamined within six weeks after discharge from the hospital. Postoperative therapy usually included radiotherapy and one patient received blind radiotherapy.

The success of therapy was determined on the basis of the clinical outcomes and serial MRI scans. Treatment response was radiologically defined as MRI scans demonstrating reductions in the extent of signal abnormalities with T2-weighted or fluid-attenuated inversion recovery (FLAIR) imaging sequences, MRI scans demonstrating reductions in the extent of gadoliniumenhancing tissue in cases in which enhancement was noted before the initiation of therapy, or MRI scans demonstrating stable findings (i.e., no changes, compared with pretreatment MRI scans). Treatment failure was radiologically defined as MRI evidence of more extensive T2weighted or FLAIR signal abnormalities or new appearance of gadolinium-enhancing tissue.

\section{Results}

In our series seven patients were male (47\%), and the median age at presentation was 43 years (range, 6-75 year). The median time from the onset of symptoms to diagnosis was 3 months (range, 0-12 months). The median Karnofsky Performance Scale (KPS) score for our patients was 70 (range, 50-100). The most common presenting complaints are presented in Table (2). Changes in mental status were often subtle and usually included decreased memory and/or personality changes, although one patient exhibited obtundation at initial presentation. No headache pattern was particularly common, and patients complained of frontal, retro-orbital, and vertex headaches equally. Seven patients presented with seizures.

In radiological study of our series MRI scans were obtained for all patients, and representative findings are presented in Figures 1, 2, 3. T1 \& T2-weighted, proton-density, and FLAIR imaging scans were used to assess the full extent of the tumors. The MRI findings for our study population are summarized in Table [3]. All patients demonstrated tumor involvement of at least two cerebral lobes, and some demonstrated involvement of more than two lobes $40 \%$. Among the patients with unilateral disease $34 \%$, two patients (14\%) had right-hemispheric disease, whereas threepatients (20\%) had left-hemispheric disease. Patients with MRI scans demonstrating enhancement were six $(40 \%)$ and were more likely to have higher-grade. 
Nine patients underwent biopsy, either stereotactic (five patients) or open (four patients), and five patients underwent craniotomy and subtotal resection of a focal mass at the time of initial surgical treatment. The choice of stereotactic versus open biopsy reflected surgeon preferences and did not seem to be correlated with any radiological findings (e.g., dominant mass or subcortical versus deep gray matter involvement).

Of the fifteen patients in this series, fourteen (93\%) had tissue specimens that were diagnostic for astrocytomas of differing grades. One patient (7\%) had a Grade 2 tumor, six patients (40\%) had Grade 3 tumors, and seven patients (47\%) had Grade 4 tumors. All of those tumors exhibited astrocytic features, with only one of the specimens also exhibiting evidence of oligodendroglial neoplasia.

The median length of survival (LOS) from the time of diagnosis for all fifteen patients in our study was 13 months (range, 1-32 months). Five patients are still alive, with a median follow-up period of 18 months (range, 6-32 months). The median LOS from the time of diagnosis for the patients who died was 11 months (range, 1-28 months). Younger patients and patients with better Karnofsky performance scale (KPS) scores were more likely to obtain treatment. One patient who received blind radiotherapy demonstrated KPS scores of 50 and aged 75 years (Table 1). This patient quickly died as a result of his disease 1 month after diagnosis and radiotherapy.

Radiotherapy was given for fifteen patients (100\%) (Table 4), including one patient for whom no biopsy was taken. For almost all of the patients, 5400 to $6100 \mathrm{cGy}$ was delivered with routine fractionated treatment plans administered in four to six weeks; the only exceptions were two adult patients who died during 1 month of radiotherapy, and a pediatric patient who received 3000 cGy because of her age.

Statistical analysis demonstrated median LOS values for patients who received different treatments as follows: blind radiotherapy, 1 month $[\mathrm{n}=1]$; Biopsy then radiotherapy, 19 months (8-32 months; $\mathrm{n}=9$ ); Subtotal excision then radiotherapy, 5 months (1-7 months; $\mathrm{n}=5$ ). The interpretation of these data is limited by the small sample size, short time of data collection and follow up and the extent of censoring (five patients living at the conclusion of the study).

Univariate regression analyses of data for all cases revealed that the following factors were correlated with increased LOS: KPS score of $\geq 70(n=12)$, absence of enhancement on MRI scans $(n=9)$, and lower tumor grade $(n=7)($ Table 5$)$.

Table 1. Patient characteristics, tumor grades, treatments, and length of survival for the study population 


\begin{tabular}{|c|c|c|c|c|c|c|c|}
\hline $\begin{array}{l}\text { Patient } \\
\text { no. }\end{array}$ & $\begin{array}{l}\text { Patient } \\
\text { characteristics } \\
\text { Sex / age } \\
\text { [years] }\end{array}$ & Presentations & $\begin{array}{l}\text { KPS } \\
\text { Score }\end{array}$ & Grade & Treatment & $\begin{array}{l}\text { LOS } \\
\text { [months] }\end{array}$ & Alive \\
\hline 1 & F/ 47 & $\begin{array}{l}\text { Dementia, } \\
\text { hemiparesis }\end{array}$ & 70 & 3 & $\begin{array}{ll}\text { Biopsy } \quad+ \\
\text { XRT }\end{array}$ & 28 & \\
\hline 2 & $\mathrm{M} / 57$ & $\begin{array}{l}\text { Seizures, } \\
\text { hemiparesis, } \\
\text { dementia }\end{array}$ & 80 & 4 & $\begin{array}{ll}\text { Biopsy } \quad+ \\
\text { XRT }\end{array}$ & 17 & \\
\hline 3 & F/56 & $\begin{array}{l}\text { Seizures, } \\
\text { hemiparesis }\end{array}$ & 90 & 4 & $\begin{array}{l}\text { Subtotal } \\
\text { excision }+ \\
\text { XRT }\end{array}$ & 7 & \\
\hline 4 & $\mathrm{M} / 75$ & $\begin{array}{l}\text { Seizures, } \\
\text { headache, nausea, } \\
\text { dementia }\end{array}$ & 50 & - & Blind XRT & 1 & \\
\hline 5 & $\mathrm{M} / 27$ & $\begin{array}{l}\text { Headache, } \\
\text { decreased } \\
\text { peripheral vision }\end{array}$ & 90 & 4 & $\begin{array}{ll}\text { Biopsy } \quad+ \\
\text { XRT }\end{array}$ & 9 & + \\
\hline$\overline{6}$ & $\mathrm{~F} / 25$ & Headache & 100 & 2 & $\begin{array}{ll}\text { Biopsy } \quad+ \\
\text { XRT }\end{array}$ & 32 & + \\
\hline 7 & $\mathrm{~F} / 6$ & $\begin{array}{l}\text { Seizures, nausea, } \\
\text { obtundation }\end{array}$ & 60 & 4 & $\begin{array}{l}\text { Subtotal } \\
\text { excision }+ \\
\text { XRT }\end{array}$ & 6 & \\
\hline 8 & $\mathrm{M} / 56$ & Seizure, dementia & 80 & 3 & $\begin{array}{ll}\text { Biopsy } \quad+ \\
\text { XRT }\end{array}$ & 15 & \\
\hline 9 & $\mathrm{~F} / 34$ & $\begin{array}{l}\text { Headache, } \\
\text { nausea, dementia }\end{array}$ & 90 & 4 & $\begin{array}{l}\text { Subtotal } \\
\text { excision }+ \\
\text { XRT }\end{array}$ & 1 & \\
\hline 10 & $\mathrm{M} / 42$ & $\begin{array}{l}\text { Headache, } \\
\text { hemiparesis }\end{array}$ & 80 & 4 & $\begin{array}{ll}\text { Biopsy } \quad+ \\
\text { XRT }\end{array}$ & 19 & + \\
\hline 11 & $\mathrm{M} / 34$ & $\begin{array}{l}\text { Headache, nausea, } \\
\text { dementia }\end{array}$ & 90 & 3 & $\begin{array}{ll}\text { Biopsy } \quad+ \\
\text { XRT }\end{array}$ & 18 & + \\
\hline
\end{tabular}




\begin{tabular}{|c|c|c|c|c|c|c|c|c|}
\hline 12 & $\mathrm{~F} / 35$ & Dementia & 90 & 3 & $\begin{array}{l}\text { Biopsy } \\
\text { XRT }\end{array}$ & & 27 & + \\
\hline 13 & $\mathrm{~F} / 48$ & $\begin{array}{l}\text { Dementia, } \\
\text { homonymous } \\
\text { hemianopsia }\end{array}$ & 70 & 4 & $\begin{array}{l}\text { Subtotal } \\
\text { excision } \\
\text { XRT }\end{array}$ & & 3 & \\
\hline 14 & $\mathrm{M} / 68$ & $\begin{array}{l}\text { Seizures, aphasia, } \\
\text { hemiparesis }\end{array}$ & 60 & 3 & $\begin{array}{l}\text { Biopsy } \\
\text { XRT }\end{array}$ & & 8 & \\
\hline 15 & $\mathrm{~F} / 30$ & $\begin{array}{l}\text { Headache, } \\
\text { seizures, } \\
\text { hemiparesis }\end{array}$ & 70 & 3 & $\begin{array}{l}\text { Subtotal } \\
\text { excision } \\
\text { XRT }\end{array}$ & & 6 & \\
\hline
\end{tabular}

$\mathrm{No}=$ number, $\mathrm{Yr}=$ year, $\mathrm{mo}=$ months, KPS $=$ Karnofsky Performance Scale, LOS $=$ Length of Survival, $\mathrm{F}=$ Female, $\mathrm{M}=$ Male and XRT= Radiotherapy.

Table 2. Presenting complaints and deficits in the study population.

\begin{tabular}{|l|l|}
\hline Presenting complaints & No. of patients \\
\hline Mental status changes & $8[54 \%]$ \\
\hline Seizures & $7[47 \%]$ \\
\hline Headaches & $7[47 \%]$ \\
\hline Nausea & $4[27 \%]$ \\
\hline Gait changes & $6[40 \%]$ \\
\hline Weakness & $6[40 \%]$ \\
\hline Visual changes & $2[14 \%]$ \\
\hline
\end{tabular}

Table 3. Magnetic resonance imaging finding for the study population 


\begin{tabular}{|l|l|l|}
\hline \multicolumn{2}{|l|}{ Finding } & No. of patients \\
\hline No. of lobes & 2 & \\
\hline & 3 & $9[60 \%]$ \\
\hline & 4 & $4[26 \%]$ \\
\hline Location & $2[14 \%]$ \\
\hline Cerebral hemisphere & \\
\hline Diencephalon / basal ganglia & $15[100 \%]$ \\
\hline Brain stem & $12[80 \%]$ \\
\hline Left & $3[20 \%]$ \\
\hline Right & $3[20 \%]$ \\
\hline Bilateral & $2[14 \%]$ \\
\hline Mass effect & $10[66 \%]$ \\
\hline Enhacement & $8[53 \%]$ \\
\hline Cyst & $6[40 \%]$ \\
\hline Hydrocephalous & $1[7 \%]$ \\
\hline
\end{tabular}

Table 4. Different treatment strategies

\begin{tabular}{|l|l|l|l|}
\hline Treatment & $\begin{array}{l}\text { No. of } \\
\text { patients }\end{array}$ & $\begin{array}{l}\text { No. } \\
\text { alive }\end{array}$ & $\begin{array}{l}\text { No } \\
\text { dead }\end{array}$ \\
\hline Blind radiotherapy & 1 & - & 1 \\
\hline Biopsy + radiotherapy & 9 & 5 & 4 \\
\hline Subtotal excision + radiotherapy & 5 & - & 5 \\
\hline
\end{tabular}


Table 5. Results of Univariate regression analysis, identifying factors that were significantly correlated with length of survival among patient with GC.

\begin{tabular}{|l|l|l|l|}
\hline Covariate & Median [month] & $\begin{array}{l}\text { Confidence interval } \\
{[\text { month }]}\end{array}$ & No. of patients \\
\hline KPS score & \multicolumn{3}{|l|}{} \\
\hline$\geq 70$ & 13 & $1-32$ & 12 \\
\hline$<70$ & 5 & $1-8$ & 3 \\
\hline Enhancement & \multicolumn{3}{|l|}{} \\
\hline No & 18 & $6-32$ & 9 \\
\hline Yes & 6 & $1-9$ & 6 \\
\hline Grade & \multicolumn{3}{|l|}{} \\
\hline 2 & 32 & 32 & 1 \\
\hline 3 & 17 & $6-28$ & 6 \\
\hline 4 & 9 & $1-19$ & 7 \\
\hline
\end{tabular}

No= number, KPS= Karnofsky Performance Scale.

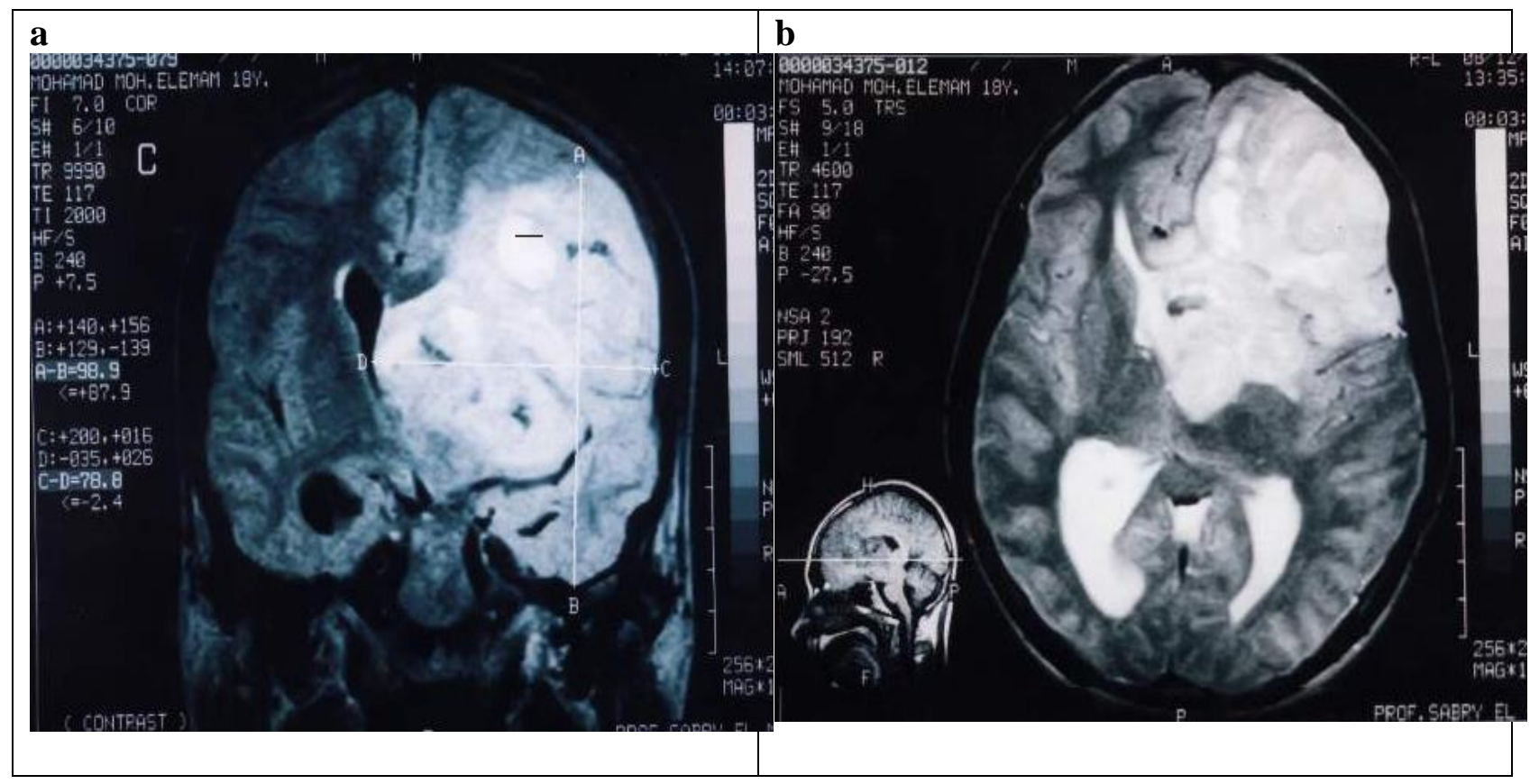


Figure 1: 47 years old female patient presented with symptoms of dementia and right hemiparesis a : Contrast-enhanced coronal T1- weighted image demonstrates evidence of contrast enhancement of left huge tempro-parietal mass with midline shift. B: MRI brain axial cut demonstrating, within the brain parenchyma, extensive high signal changes in the T2-weighted images, maximal in the frontal lobe and extend to the parietal lobe on the left side.

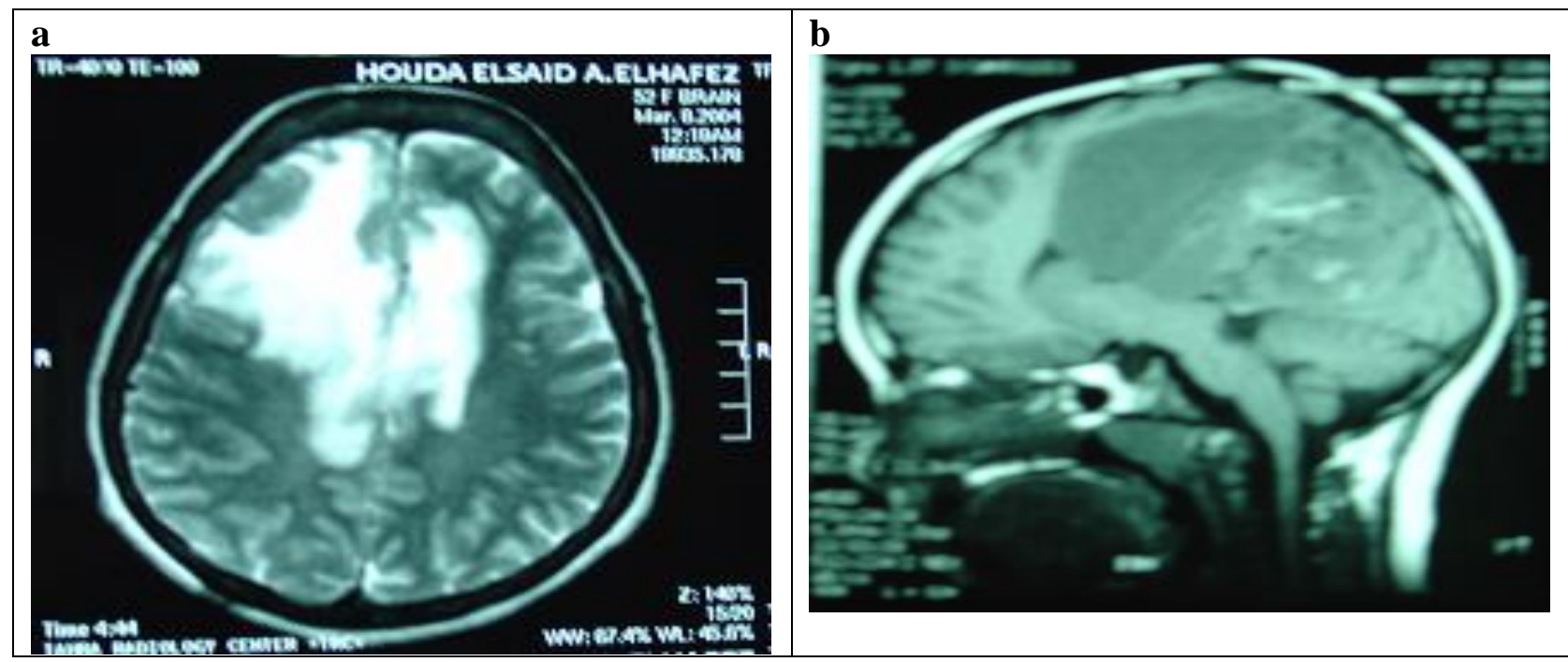

Figure 2: a: MRI brain axial cut demonstrating, within the brain parenchyma, extensive high signal changes in the T2-weighted images, in the bilateral frontal lobes. B: MRI brain sagittal cut demonstrating, within the brain parenchyma, extensive lesion in the T1-weighted images. Evidence of biopsy from the parietal lobe.

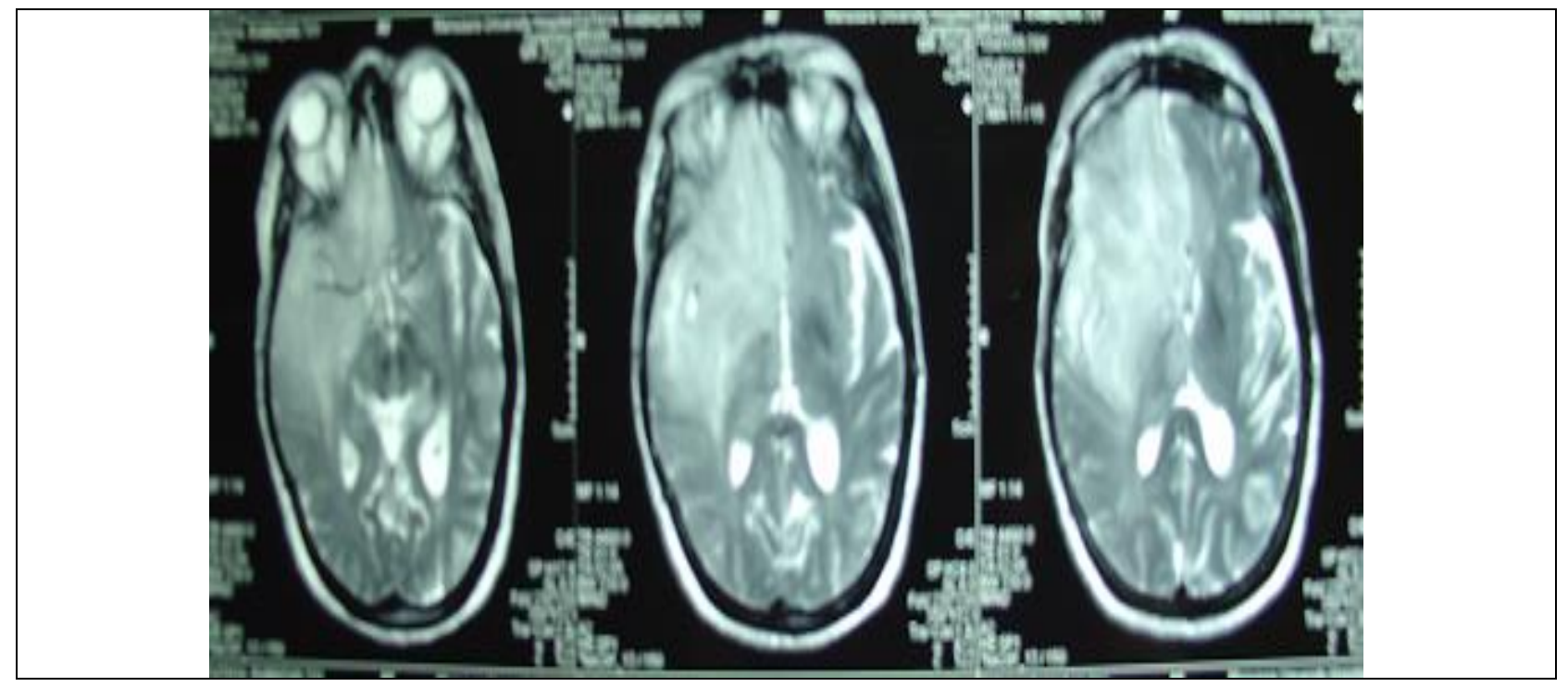


Figure 3: MRI brain axial cuts demonstrating, within the brain parenchyma, extensive lesion in the T2-weighted images involving the right frontal, temporal and parietal lobes.

\section{Discussion}

Our work is an evaluation of the physical and radiological findings, tumor pathological features, and treatment outcomes for GC patients to define the best strategy for management.

Clinical findings are usually indirect and nonspecific, though the occurrence of specific findings varies among different studies [5-7, 10-15]. Subtle cognitive and emotional alterations occur before dementia that develops later in the course of GC. Clinical, neuroimaging, and neuropathological data suggest that the white matter is damaged directly by the tumor and this is associated with mild edema, although infiltration of subcortical and cortical gray matter also occurs to a variable extent $[3,6]$. GC is considered a cause of white matter dementia due to favored neoplastic disruption of the white matter tracts. The duration of symptoms before diagnosis also varies among different patients, reflecting differences in tumor invasion aggressiveness. Because neoplastic cells in GC invade brain tissue without much disruption of neuronal numbers or architectural features [11, 14]. GC may have a more mysterious presentation than other gliomas, which are more disruptive of the adjacent neurons. Still, GC is similar to other forms of glioma, it can present among patients of all ages but preferentially occurs in the third or fourth decade of life and the functional status of patients at the time of diagnosis seems to be correlated with the LOS from the time of diagnosis [5].

The MRI findings for patients with GC are dramatic than the patients' symptoms suggest. Reports differ with respect to the number of cerebral lobes involved and whether infratentorial structures are commonly affected [5, 6, 10-12, 14-17]. Studies agree that the hallmark of GC is widespread invasion of the brain by tumor cells. With the increased sensitivity of T2-weighted and FLAIR sequences, however, MRI improves accurate diagnoses by demonstrating the true extent of abnormal brain tissue for patients with nonspecific symptoms. One study evaluated the diagnostic potential of FLAIR MR imaging in patients with suspected GC. Seven patients suspected of having lesions of GC were examined by T1-weighted spin echo [SE], T2-weighted fast spin echo [FSE], and FLAIR MR imaging with identical slice parameters. After contrast media administration $\mathrm{T} 1$ and FLAIR were repeated. The primary parameters of the image analysis were the delineation and extent of gliomatosis tumor. The FLAIR imaging clearly delineated the extent of gliomatosis lesions in all patients. Due to the suppression of cerebrospinal fluid, the delineation was superior to conventional T2-weighted FSE images. The FLAIR images showed the delineation of cortical spread and the corpus callosum infiltration. The FLAIR MR imaging is considered a valuable diagnostic modality in the assessment of 
patients with GC. The FLAIR MR imaging is considered the imaging method of choice and should be integrated into the MR imaging protocol of Gc patients diagnosis $[5,18,19]$.

Tissue biobsy confirmation remains important for the detection of pseudotumor cerebri, leukoencephalopathy, various dementing illnesses, multiple sclerosis, encephalitis, and hemimegalencephaly [10]. Those diseases could present with similar clinical and radiological findings.

\section{Treatment and Outcomes}

Because of the relative rarity of GC and the perception that GC carries a uniformly grim prognosis $[4,6,7,14,15,10,20,21]$, few researchers have examined the effects of treatment on outcomes. Our data suggest that patients treated with radiotherapy live longer than untreated patients. Kim et al. [11] and Horst et al. [9] suggested that radiotherapy is beneficial, and the median LOS for our treated patients was similar to the median LOS in their reports. Neither of those earlier reports included patients who were not treated, however, and those reports thus could not confirm the effectiveness of treatment. Moreover, Horst et al. [9] extracted most of their data from case reports in the literature and included only three patients who were treated at their institution. Elshaikh et al. [7] compared results for patients treated with or without radiotherapy [ $\mathrm{n}=8$ and 4 , respectively]; their results were similar to ours, although the numbers of patients were smaller. The number of patients in our prospective study is small, and it is likely that age or KPS scores were confounding variables in our analysis.

KPS scores and grade seem to be correlated with LOS among patients with GC, similar to the correlations between these factors and LOS among patients with other forms of glioma [22]; also, age at presentation seem to influence LOS. These findings suggest that KPS scores, tumor grades and age may be important for treatment planning, strongly arguing for biopsies for all patients for whom GC is suspected. However, it is not possible to state whether there are cutoff values for KPS scores and grades that would preclude treatment. Further studies of the benefits of different treatments, the importance of different histological or genetic markers, and treatment strategies must control for KPS scores and grade.

GC is very different from other forms of glioma. For example, GC is characterized by widespread dissemination of tumor cells; other gliomas are widely infiltrative but are not as disseminated at presentation.

But GC, like other forms of glioma, occurs in varying grades and can be either indolent or rapidly progressive. Patient survival rates are correlated with KPS scores and tumor grade. What seems to best define the difference between GC and other forms of glioma is the disparity between the amount of diseased brain tissue and the neurological findings. 
Although the small number of patients in our study may hinder reaching definitive recommendations regarding the treatment, our findings suggest that treatment can increase LOS and that biopsies are useful not only for diagnosis of the disease but also for prediction of LOS.

\section{Conclusion}

Patients with GC can present with subtle neurological findings. MRI and biopsies are useful for diagnosis, and determination of survival rates and potential treatment approaches. The accuracy of estimations of tumor grade is correlated with LOS. Surgery is not practical considering the extent of the disease Radiotherapy, may be useful in prolonging survival.

\section{REFERENCES}

1-Nevin S: GC. Brain. 61:170191, 1938.

2-Broniscer, A, Omar C, Scott H, Tong L, Stanley P, et al.: "GC in children shares molecular characteristics with other pediatric gliomas." Acta neuropathologica 131 [2]: 299-307, 2016.

3-Kleihues P and Cavenee WK: Pathology and Genetics of Tumors of the Nervous System.Lyon, IARC Press, 2000.

4-Artigas J, Cervos-Navarro J, Iglesias JR, Ebhardt G: GC: clinical and histological findings. Clin Neuropathol; 4:135-148, 1985

5-Del Carpio-O'Donovan R, Korah I, Salazar A, Melancon D: GC. Radiology. 198:831835, 1996

6-Couch JR, Weiss SA: GC: Neurology. 24:504511, 1974.

7-Elshaikh MA, Stevens GH, Peereboom DM, Cohen BH, Prayson RA, Lee SY, et al: GC:. Cancer. 95:20272031, 2002.

8-Ross IB, Robitaille Y, Villemure JG, Tampieri D: Diagnosis and management of GC: Surg Neurol. 36:431440, 1991.

9-Horst E, Micke O, Romppainen ML, Pyhtinen J, Paulus W, Schafer U, et al: Radiation therapy approach in GC:. Acta Oncol. 39:747751, 2000.

10-Jennings MT, Frenchman M, Shehab T, Johnson MD, Creasy J, LaPorte K, Dettbarn WD: GC presenting as intractable epilepsy during early childhood. J Child Neurol. 10:3745, 1995.

11-Kim DG, Yang HJ, Park IA, Chi JG, Jung HW, Han DH, Choi KS, Cho BK: GC:. Acta Neurochir [Wien]. 140:755762, 1998. 
12-Koslow SA, Claassen D, Hirsch WL, Jungreis CA: GC: a case report with autopsy correlation. Neuroradiol; 34:331-333; 1992.

13-Ponce P, Alvarez-Santullano MV, Otermin E, Santana MA, Garcia Ludena MV: GC:. Eur J Radiol. 28:226229, 1998.

14-Mineura K, Sasjima T, Kowada M et al: Innovative approach in the diagnosis of GC using carbon-11-L-methionine position emission tomography, J Nuc Med; 32:726-728; 1991.

15-Shin YM, Chang KH, Han MH, Myung NH, Chi JG, Cha SH et al: GC:. AJR Am J Roentgenol. 161:859862, 1993.

16-Freund M, Hahnel S, Sommer C, Martmann M, Kiessling M, Tronnier V, Sartor K: CT and MRI findings in GC:. Eur Radiol. 11:309316, 2001.

17-George, Emilie, Allison S, Scott C, Jeffrey P.: "Pediatric GC A Review of 15 Years." Journal of child neurology 31 [3]: 378-387, 2016.

18-Felsberg GJ, Silver SA, Brown MT, Tien RD: Radiologic-pathologic correlation:AJNR Am J Neuroradiol. 15:17451753, 1994.

19-Scheinker M and Evans JP: Diffuse cerebral glioblastosis. J Neuropathol Exp Neurol; 2:178-89; 1943.

20-Cozad SC, Townsend P, Morantz RA, Jenny AB, Kepes JJ, Smalley SR: GC:. Cancer. 78:17891793, 1996.

21-Kandler RH, Smith CM, Broome JC, Davies-Jones GA: GC:Br J Neurosurg. 5:187193, 1991.

22-Curran WJ, Scott CB, Horton J, Nelson JS, Weinstein AS, Fischbach AJ, Chang CH, et al: Recursive partitioning analysis of prognostic factors in three Radiation Therapy Oncology Group malignant glioma trials. J Nat Cancer Inst. 85:704710, 1993 